\title{
茄青枯病に關する研究*
}

\author{
I. 寄主反應の品種間差異に就々て \\ 國 枝 鐄 造** \\ Kozo Kunieda: Studies on the bacterial wilt of eggplants. \\ I. Varietial differences of hosts in reaction \\ to the causal bacteria.
}

Pseudomonas solanacearum の侵害に基因する茄 科植物青枯病はその病攀の裁烈性, 藥劑防除の困難性 から，圊埸に於ける農作物細菌病害中最子怖れられて いるすののーつである。

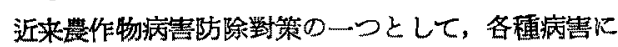

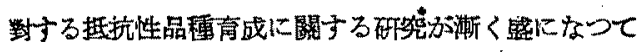
きた。しかしその矿究完成に極めて雷要である抵抗性

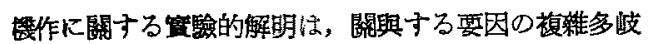
性から，その殆んぞが末だ混沌の城を眖しない狀態に 古方。

茄科植物青枯病に能いて，吉井・西澤(8)は垔草立枯

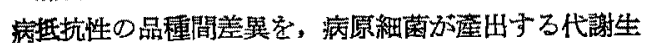

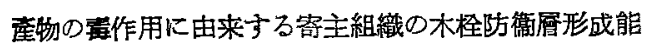
にての最大要因を求めている。茄及び蕃茄の青枯病抵

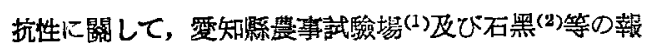
告によれば，概して蕃茄は乞の抵拉性が不安定て，外

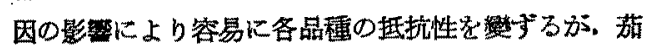

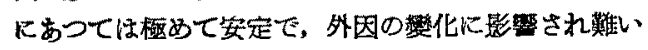
ものの如くである。しかしながらその抵抗性機作に就 いては，未だ何等葢驗的解明はなされていない。唯蕃

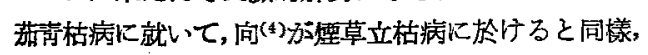

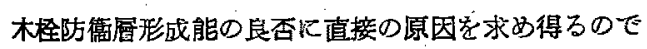
はないかと推察しているに過ざない。

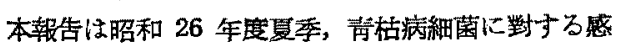

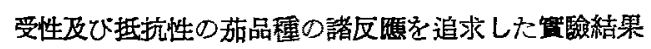
である。起䄸に當り，贵重な純系品種の茄種子を分挔

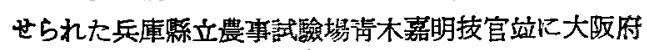

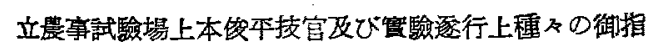

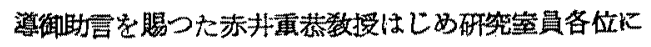
深些なる感謝を溌げる。

\section{I. 贯驗の材料}

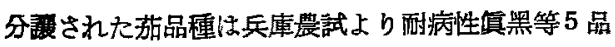

\footnotetext{
* 京都大照植物病理學研究室業綪, No. 21. 本諭交

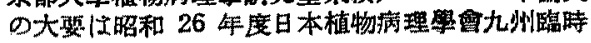
大曾にて發表。

** 兵䓬縣立農業短期大學
}

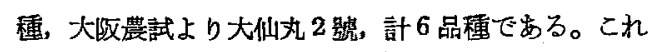

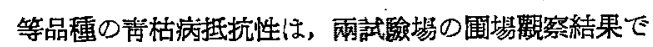

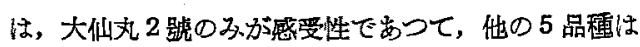

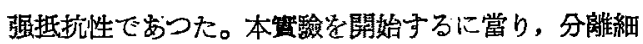

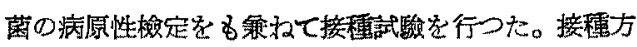
法は各 1 本宛鈢植した茄の主苝地際部の周国約 $5 \mathrm{~cm}$ の部分を小刀で笑いて根部に附賃せしめたものと; 主 蔯地際部门約 $1 \mathrm{~cm}$ の烈㑺を與えたるのとについて, 常法の如く行つた。接種原は7月10日,京都市北白川

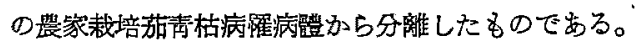
接種 3 週間後に，外見的病徽により，大仙丸 2 號は感

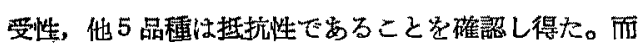

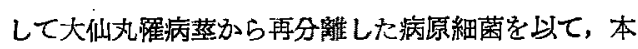

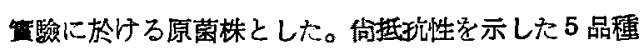
の万ち，大仙丸 2 號と生育度等に於て相似型ですると 見られる酎病性真黑を抵抗性品種の代表とし，主とし てこの 2 品檑を宽驗に代した。

\section{II. 接種植物體の解剖淟的覟察}

接種試孜を行つた大仙丸，真黑雨品穆では，抵抗性 である稘黑は對照區のものと殆んど變化なく，全く健 全であると思われたが，火仙丸では全䒚藏變して枯死

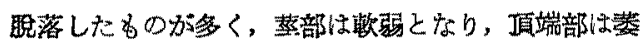
调して, 典型的な青枯病牀学呈していた。雨稙物とも 根を損しないよらに水道水で砂を洗滥したところ， 大仙丸に於ては接種時切断した根部の再生少く，真黑 の旺盛な根群化比べ全く對照的であつた。兩植物の主

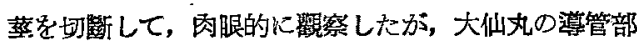

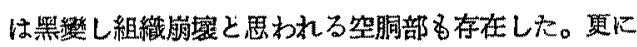
常法により兩㩐より接種菌の再分踓老行つたが，真黑 㩐からは全く病原細菌空分離し得なかつた。

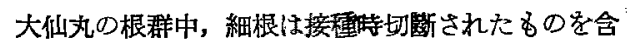
めて, 䊽て皮層部が軟原狀に黑變し, 容易に脫落して 細絲狀となり，玨しく臲弱化していた。而してその病

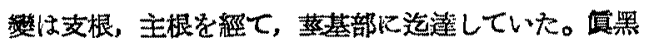
では，細根中には同樣に皮層か脱落するものも多から 


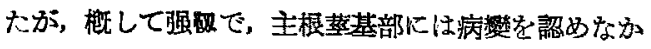
つた。接栢时に切邀された雨品種の文根に於ては, 切 斷部から 約 $10 \mathrm{~mm}$ 前後迄袏變して, その徒手切片 をphloroglucine-睤酸洗により檢鏡したところ，木柽 防衙層の形成を認めた。併し雨品種間仙は形成程庭に

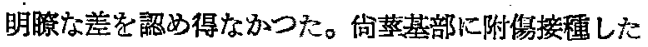

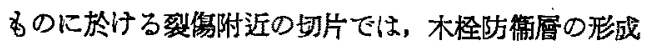
は明かでなかつた。

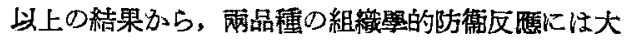
差がないものと推祭せられる。

\section{III. 植物體港出物の病原細菌

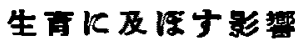

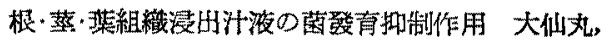
具黑雨品種の髅各部位浸出汁液が棐枯病原細菌の生理 作用に如何なる影整を及ばすかに就いて，次の方法に

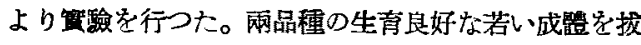
き取つて, 水道水でよく洗嫁した後，根 $1 \mathrm{~g}$, 蒸 $3 \mathrm{~g}$ 仪

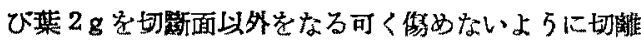
して, 各融別に 殺菌蒸溜水 $100 \mathrm{cc}$ 中に浮へ，室溫暗 所で 24 時間静置した。その浸出液に㪱め殺菌した直

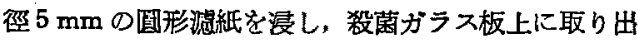

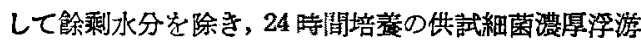

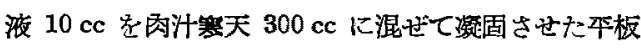
上に立三， $36^{\circ} \mathrm{C} 24$ 時間後，圆形感紙周國に現われた

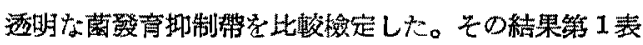

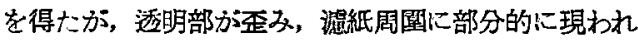

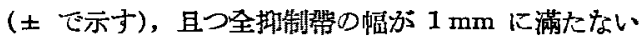
るのであつたため, 数量的には比較し得なかつた。倍

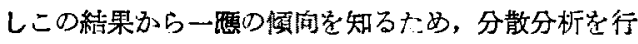
つたところ, 各組繶部值間に有意差が認められ，根組

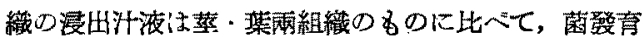
抑制作用が强い上万ですつたが，兩品種間の倳異法認 められなかつた。

第 1 表

\begin{tabular}{|c|c|c|c|c|}
\hline 品 種 & 筫驗別 & 根 & 荭 & 苕 \\
\hline $\begin{array}{c}\text { 太仙热 } \\
\text { 號 }\end{array}$ & $\begin{array}{l}1 \\
2\end{array}$ & $\begin{array}{l}- \pm \pm \pm \\
----\end{array}$ & -- & $\begin{array}{l}-+ \pm- \\
----\end{array}$ \\
\hline 而病监 & $\begin{array}{l}1 \\
2\end{array}$ & $\begin{array}{l} \pm \pm \pm \pm \\
-- \pm \pm\end{array}$ & ---- & $\begin{array}{l}-ー-ー \\
---ー\end{array}$ \\
\hline
\end{tabular}

集表面に附着せしめた菌の發育，前缶驗に於て的破

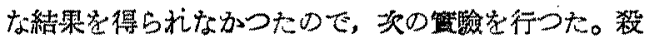

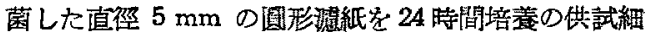

菌浮游液に浸し，殺菌ガラス板上にのせて餘剩成汾是 除いて，大仙丸，具黑各 3 株の同一焦位の集を選九て，

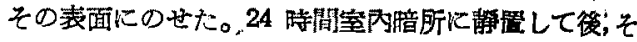
の㴔紙中の生菌數管常法により測定したが，對照とし て籼菌スライドに附着させて, 底部に少量の水を入れ た無蓋圆筒瓶中に保つたすの在測定した。省聚落計算

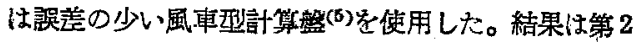
表の如くでする。

第 2 表

\begin{tabular}{|c|c|c|c|c|c|}
\hline 種 & 實羷別 & 葉 1 & 葉 2 & 葉 $\mathbf{3}$ & 䓧 \\
\hline 大仙丸 2 號 & $\begin{array}{l}1 \\
2\end{array}$ & $\begin{array}{l}15 \\
22 \\
\end{array}$ & $\begin{array}{l}20 \\
16 \\
\end{array}$ & $\begin{array}{l}12 \\
13 \\
\end{array}$ & $\begin{array}{l}2 \\
0\end{array}$ \\
\hline 酎病性䢜黑 & $\begin{array}{l}1 \\
2\end{array}$ & $\begin{array}{l}4 \\
6\end{array}$ & $\begin{array}{r}6 \\
11\end{array}$ & $\begin{array}{l}4 \\
8\end{array}$ & $\begin{array}{l}4 \\
2\end{array}$ \\
\hline 照 & $\begin{array}{l}1 \\
2\end{array}$ & $\begin{array}{l}1 \\
0\end{array}$ & $\begin{array}{l}2 \\
1\end{array}$ & $\begin{array}{l}0 \\
4\end{array}$ & $\overline{=}$ \\
\hline
\end{tabular}

上表の結果では，检定により有意な品種間差異か証 められた。郎ち抵抗性品種面黑の荣面に附着した青枯 病原細菌は,.24 時間後自然淢亭と看做される對照區の ○より生菌数は多いが，感受性蜎種の大仙丸の葉面 に附着したるのより明か心少く，珈䈎面に青枯病原細 菌の發育促進或は抑制作用有与る出物方存在して いることを暗示するよらである。一方兩品種の萓面に 附着させたものは，對照區と同椄の隇衰度をあらわし， 洛出作用は葬部に於ては認められなかつた。

\section{IV. 植物體內組成の病原細菌 生青に及添影響}

根・菜・集組織攡汁液の菌發有抑制作用 以上の結 果から, 抵抗性, 感受性兩品種の照內組成の相䔔方病

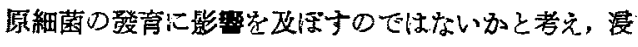

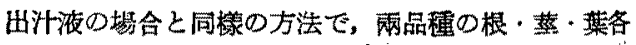

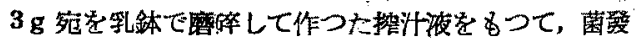
育抑制帶の比較も行つた。乙の結果第3 表の如く,

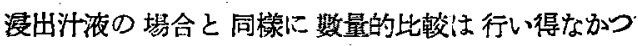
た。检定の結果, 品璉間の差は認められなかつたが, 組織部位間には有意恙が認められ，根部の揣田汗液の

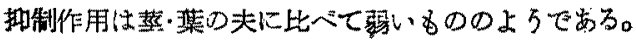

第 3 表

\begin{tabular}{|c|c|c|c|c|}
\hline 品 種 & 赛驗別 & 松 & 蕉 & 葉 \\
\hline 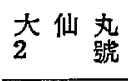 & $\begin{array}{l}1 \\
2\end{array}$ & $\begin{array}{l}---- \\
--- \pm\end{array}$ & $\begin{array}{l} \pm+++ \\
\pm+++\end{array}$ & \\
\hline 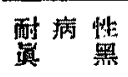 & $\begin{array}{l}1 \\
2\end{array}$ & $\begin{array}{l}--- \\
---\end{array}$ & $\begin{array}{l}++++ \\
++++\end{array}$ & \\
\hline
\end{tabular}


葉租糡內注入菌の登育 搾出汁液圆形滤紙法による 路內組成の品種間差位と病原細菌生理作用との關係に 好綃果を得られなかつたので，生集心面接菌を注入し

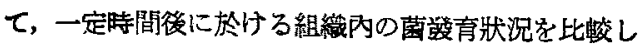

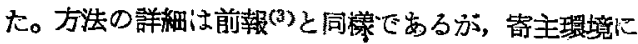
關子る要因を省き，寄主の種類のみを要因として計墨 し, 生菌數は 24 時間及び 48 時間後のものを湘定し

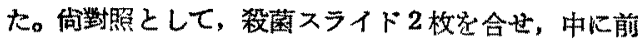

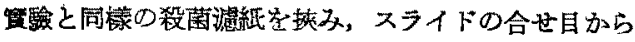

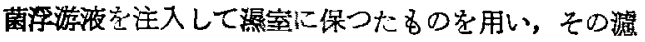
紙中の生菌數を测定した。24 㭙間後の测定值を第 4 表 に, 48 時間後の測定值第 5 表に䌆めて示した。

\begin{tabular}{|c|c|c|}
\hline $\begin{array}{l}\text { 大仙势 } \\
2\end{array}$ & 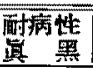 & 数照區 \\
\hline $\begin{array}{l}79 \\
73 \\
84 \\
75\end{array}$ & $\begin{array}{l}56 \\
55 \\
41 \\
32\end{array}$ & $\begin{array}{r}119 \\
77 \\
101 \\
.64\end{array}$ \\
\hline
\end{tabular}

\begin{tabular}{|c|c|c|}
\hline 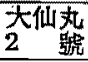 & $\begin{array}{l}\text { 耐病性 } \\
\text { 墨 }\end{array}$ & 對照區 \\
\hline $\begin{array}{l}376 \\
388 \\
485 \\
504\end{array}$ & $\begin{array}{l}\mathbf{5 2} \\
\mathbf{5 3} \\
\mathbf{5 5} \\
\mathbf{5 1}\end{array}$ & $\begin{array}{l}22 \\
38 \\
30 \\
39\end{array}$ \\
\hline
\end{tabular}

兩表に基き，供試 3 逼の生菌敗它比輍检定すると，

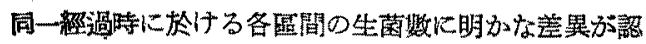
められ，更に之の堆碝の㭙間的經過に於ても各區間と るに有意差ふ認められた。郎ちその機作が化學的であ るか，生理的であるが明かでないが，感受性の組織 にあつては病原細菌の堙雃を阻害しないのに反して， 热抗性組織內には, その霄殖を注入 24 時間後に於て

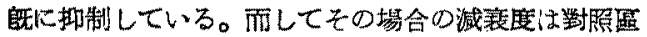
の示す自然的なると鸟異つた傾向を有しているもの のよ5に推察された。

Paper-chromatography により分配された寄主成分 の菌發育に及ほすす影譬 前空簽に示された組織內生菌

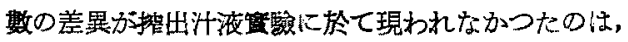
汁液中に多量に含まれている集緣菜の影淛が主因とな

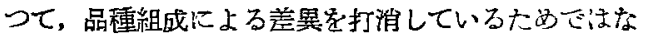

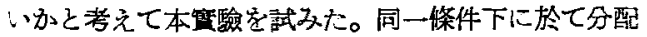
された各物資ゆ Rf 價は一定ですると看做し得るとす

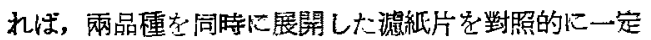

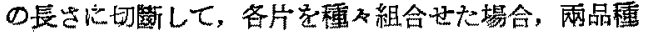

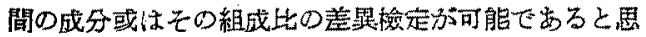
われる。而して检定の方法として組合せた䦪紙片を殺 菌蒸溜水中に浸青して，ちの浸出液中に於ける病原細 菌の發育度を比較することとし，次の如き操作を行つ

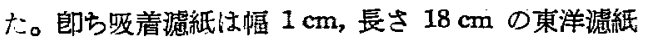
No.2 を用い, 兩品種の督控汁液を下端 $5 \mathrm{~cm}$ の部分

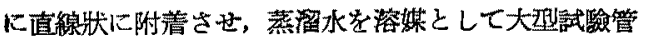

內で一次元上杽法により展開し，上端から $5 \mathrm{~cm}$ 宛切

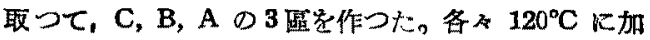

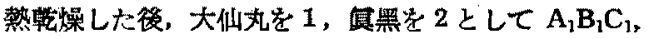
$A_{2} B_{1} C_{1}, A_{1} B_{2} C_{1}, A_{1} B_{1} C_{2}, A_{2} B_{2} C_{2}, A_{1} B_{2} C_{2}, A_{2} B_{1} C_{2}$ $\mathrm{A}_{2} \mathrm{~B}_{2} \mathrm{C}_{1}$, の 8 種の組合せ要作方て，各及 $10 \mathrm{cc}$ の殺菌 蒸溜水を含む試臉管中に入れ，各及 24 特間培養菌の 蒸溜水浮游液を 1 白金耳宛接種して，48 時间 $30^{\circ} \mathrm{C}$ に

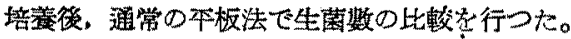

\begin{tabular}{|c|c|c|c|c|c|}
\hline & \multirow{2}{*}{ 實驗別 } & \multicolumn{2}{|c|}{$A_{1}$} & \multicolumn{2}{|c|}{$\mathbf{A}_{2}$} \\
\hline & & $\mathbf{B}_{1}$ & $\mathrm{~B}_{2}$ & $\mathrm{~B}_{1}$ & $\mathbf{B}_{2}$ \\
\hline \multirow{2}{*}{$\mathrm{C}_{\mathrm{I}}$} & 1 & 174 & 192 & 32 & 144 \\
\hline & 2 & 180 & 240 & 39 & 120 \\
\hline \multirow{2}{*}{$\mathrm{C}_{2}$} & 1 & 0 & 0 & 42 & 0 \\
\hline & 2 & 0 & 0 & 35 & 0 \\
\hline
\end{tabular}

上表の結果を分散檢定したところ， $\mathrm{C}_{2}$ 區即ら真黑成 分中て Rf>0.62 を有するすのの中に, 明かな青枯病

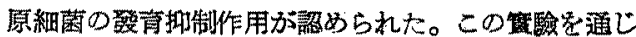

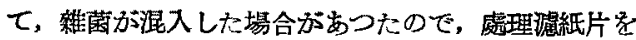

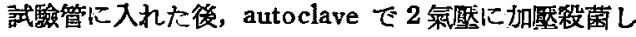
た。この場合には (第 7 表) $\mathrm{C}_{2}$ の抑制作用が失われて 何れの區も同じ儹を示した。

第 7 表

\begin{tabular}{|c|c|c|c|c|c|}
\hline & \multirow{2}{*}{ 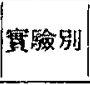 } & \multicolumn{2}{|c|}{$A_{1}$} & \multicolumn{2}{|c|}{$A_{2}$} \\
\hline . & & $\mathrm{B}_{1}$ & $\mathrm{~B}_{2}$ & $\mathrm{~B}_{\mathrm{I}}$ & $B_{2}$ \\
\hline \multirow{2}{*}{$C_{1}$} & 1 & 33 & 27 & 37 & 41 \\
\hline & 2 & 26 & 25 & 35 & 29 \\
\hline \multirow{2}{*}{$\mathrm{C}_{2}$} & 1 & 29 & 39 & 40 & 28 \\
\hline & 2 & 27 & 34 & 26 & 28 \\
\hline
\end{tabular}

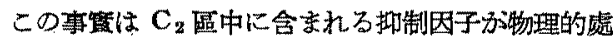
理に不安定な性筫を有していることを榎示するように 思われた。少今包は，該物質の检出は行わなかつた。

\section{V. 考察}

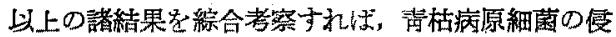

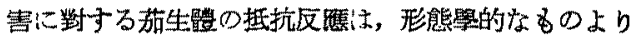
头上に，化學的，生理學的なのの作用加强く關與し ているのではないる推察せられ，同細菌の侵害に對 する煙草生體の抵抗性機作に留算する声井・西澤等(8)の 報笘と相反するものである。このことは同一病原に對 する备奇主植物の抵抗性機作を類推することの借險性 を示唆するものと思われる。 


\footnotetext{
Pseudomonas solanacearum は土惯菌であるから，

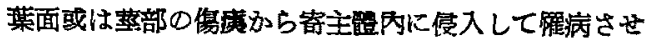

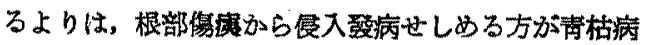
登病の主因であることは論弯の餘地がない。而して本

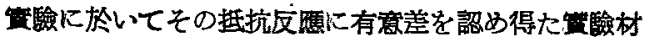
料は，变・葉組織であり，根組織を使用していない。

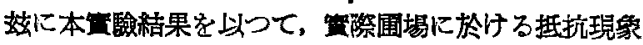
を解明しようとするには，相黨の扄險があると思う。 併し本細菌の侵䈍部は主として木筫部泿られている から，寄主反㕍の主鰽も，木質部組織及びそれに含ま れる尔散流存するのではないかと思方れ，その見地 からは根・器・葉 3 部位間比大盖がないと看做し得る のではなからうか。文一方蓧面附着菌及び葉組織內注 入菌の行動加ら，感受性品種に於ける等部鹪症口から

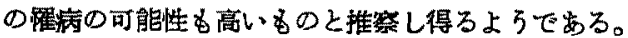
然し Simpson, Weinding ${ }^{(6)}$ 述ぺているよろに, こ

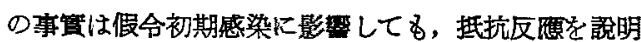
するには不充分であると思われる。組織內注入菌の增 殖に對する寄主植物の抑制反愿飞就いて，Thiers 及 Blank ${ }^{(7)}$ 汃求因した生理學的不親和性 (physiological

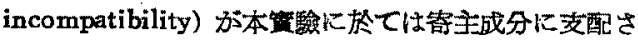
れるかの如き結果を得えが，との事筫は決して普漏性 のあるものと思われないから，特に組䋐內增茢の抑制

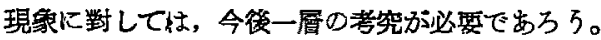
何れにしても，茄莘枯病に於ては抵抗性品稙成分中
}

に含まれ，一部㮐面加ら出している病原菌發育抑制 物盗が茄品種間の抵抗性の羙異を現出させる主要因の 一部をなしていると解格し得るすのと思われる。

\section{VI. 摘 要}

Pseudomonas solanacearum の传害に 基因する茄 青枯病の品種間抵抗性の盖異に就いて，抵抗性品種と して酎病性值黑と，感受性品種として大仙丸 2 號と完 使用して帣究した。

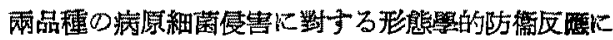
は，十分な差異は認められなかつた。葉面附着菌，葉組 裁內注入菌及び茎控出湖液の paper-chromatography 試羷等の各々に於いて, 兩品種の病原細菌發育拐制反 留に明かな品種間差異が認められた。

(昭和 27 年 12 月 11 日 受理)

\section{引1用女献}

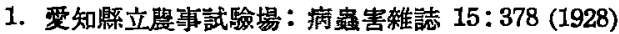

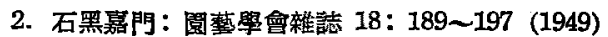

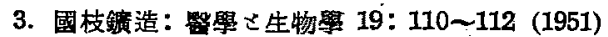

4. 向 䄧夫：典及園 26：95－98（1951）

5. 大西正男 - 加藤貞治：日本細菌學雜誌 5：233 241 (1950)

6. Shimpson, D. M. \& R. Weinding: Jour. Amer. Soc. Agron, 38: 630 635 (1946)

7. Thiers, H.D. \& L.M. Blank: Phytopath, 41 : 499 510 (1951)

8. 吉井甫・西澤正洋：日植病報 13：62（1948）

Résumé

The present paper reported the results of experiments on the varietal resistance of eggplants to the bacterial wilt disease caused by Pseudomonas solanacearum, using two varieties, Daisen Maru No. 2 (susceptible) and Durable Shinkuro (resistant). From the morphological observations, the writer found cicatrice around the affected parts of eggplants. There were no essential differences, in these morphological barriers between the two varieties used.

No definite bacteriostatic $\in$ ffect in the exuded juice from the surface of both plants or in the expressed juice of plant was observed. The growth of the bacteria on the surface of plant, however, was definitely suppressed in the resistant variety.

The writer also observed a change in the population of the pathogenic bacteria within leaf tissues of both plants after the artificial injection. After forty eight hours, the writer found a large difference in the population of bacteria in the two plant tissues, showing the acceleration in Daisen Maru and the inhibition in Durable Shinkuro.

The chromatographic separation of the expressed juice was also performed. The treated papers were cut into three parts and dried. They were called $C, B$, and $A$ from the top, respectively. $A_{1}$, $B_{1}, C_{1}$ belong to Daisen Maru, and $A_{2}, B_{2}, C_{2}$ to Durable Shinkuro. The writer extracted the substances of every part of the papers into distilled water with the following eight combinations: $A_{1} B_{1} C_{1}, A_{2} B_{1} C_{1}, A_{1} B_{2} C_{1}, A_{1} B_{1} C_{2}, A_{2} B_{2} C_{2}, A_{1} B_{2} C_{2}$, $A_{2} B_{1} C_{2}, A_{2} B_{2} C_{1}$. Thus the suppressive effect of these extracts upon bacterial growth was examined. From the results of these experiments, the writer confirmed the most strongest suppressive effect in $\mathrm{C}$ fraction of Shinkuro juice. 